\title{
Konseling Kelompok Untuk Meningkatkan Self Control pada PTRM (Program Terapi Rumatan Metadon)
}

\author{
Oleh: \\ Wahyu Utami \\ (Program Studi Psikologi Islam Institut Agama Islam Tribakti Kediri)
}

\section{Abstrak}

Subjek dalam kasus ini adalah tujuh laki-laki PTRM di kota Malang. Metode asesmen yang digunakan adalah observasi, wawancara dan skala self control. Hasil asesmen menunjukkan bahwa empat bulan terakhir dosis metadon yang diminum cenderung meningkat. Hal tersebut disebabkan karena ada beberapa permasalahan yang mereka hadapi, salah satunya yaitu pasien mendapatkan penolakan dari lingkungan sekitar dan lingkungan inti, sehingga mereka lebih nyaman untuk berkumpul dengan komunitas yang berhubungan dengan narkoba, yang menyebabkan mereka susah untuk melepaskan diri dari obat-obatan. Intervensi yang dilakukan dengan menggunakan konseling kelompok terdiri dari 6 sesi, yang bertujuan untuk meningkatkan self control untuk tidak menggunakan obat-obatan. Hasil intervensi menunjukkan bahwa subjek mampu mengontrol diri untuk tidak memakai obat-obatan terlarang, subjek juga mempunyai antisipasi alasan untuk menolak pada saat berada di kelompok pengguna narkoba.

Kata Kunci: Konseling kelompok, Self Control, Narkoba, Program Terapi Rumatan Metadon 


\section{Abstract}

The subject in this case is seven male PTRM in Malang. Assessment methods used are observation, interviews and the scale of self control. The assessment results show that the last four months of oral methadone dose increased. This is because there are some problems they face, one of which patients had resistance from the surrounding environment and the core environment, so they are more convenient to gather the community related to a drug that causes them difficult to break away from drugs. Interventions using counseling group consists of 6 sessions, which aims to improve the self-control to not use drugs. The results of the intervention showed that subjects were able to control myself not to use drugs, the subject also has a reason to reject the anticipation at the time was in a group of drug users.

Keywords: group counseling, Self Control, Drugs, Therapy Program Methadone maintenance

\section{Pendahuluan}

Penyalahgunaan Narkotika, Psikotropika dan Zat Adiktif lainnya (NAPZA) atau yang lebih sering dikenal masyarakat sebagai NARKOBA merupakan masalah yang sangat kompleks dan mengkhawatirkan dunia internasioanal United Nation Office on Drugs and Crime (UNODC) dalam World Drug Report 2008, menyebutkan bahwa satu diantara 20 orang (usia 15-64 tahun) telah mencoba Napza paling sedikit satu kali dalam 12 bulan terakhir, 0,6\% dari populasi orang dewasa di dunia mengalami ketergantungan Napza (Jurnal BNN 2009). Besarnya masalah penyalahgunaan Napza tidak hanya dilihat dari kasusnya yang semakin meningkat, tetapi juga dampak yang ditimbulkan. Dalam jurnal Napza Indonesia disebutkan bahwa pengguna Napza suntik berisiko tinggi terhadap penyakit hepatitis dan HIV/AIDS.

Cara yang lebih efektif untuk mengurangi penularan HIV melalui jarum suntik saat ini adalah melalui Harm reduction (pengurangan dampak buruk napza suntik), yang bertujuan 
meningkatkan status kesehatan penasuan. Secara komrehensif, kegiatan Harm reduction dijalankan dengan 4 cara yaitu Layanan Jarum Alat Suntik Steril (LASS), Program Terapi Rumatan Metadon (PTRM), Tes HIV, pelayanan VCT (Voluntary Counseling Testing), dan pelayanan pemulihan ketergantungan napza (Gifari, 2009).

Layanan Terapi rumatan metadon adalah sebuah terapi dimana terdapat substitusi yang mengantikan narkotika jenis heroin yang menggunakan jarum suntik yang berbentuk cair yang pemakaiannya dilakukan dengan cara diminum (BNN, 2006). Pemberian metadon tidak menimbulkan efek sedatif yang kuat. Metadon biasanya disediakan pada program pengalihan narkoba, yaitu program yang mengganti heroin yang dipakai oleh pecandu dengan obat lain yang lebih aman. Metadon bukan penyembuh untuk ketergantungan opiat: selama memakai metadon, penggunanya tetap tergantung pada opiat secara fisik. Tetapi metadon menawarkan kesempatan pada penggunanya untuk mengubah hidupnya menjadi lebih stabil dan mengurangi risiko penggunaan narkoba suntikan, dan juga mengurangi kejahatan yang terkait dengan kecanduan. Dan karena diminum, penggunaan metadon mengurangi penggunaan jarum suntik bergantian.

Program metadon sering mempunyai dua tujuan pilihan. Tujuan pertama adalah untuk membantu pengguna berhenti memakai heroin (detoksifikasi), diganti dengan takaran metadon yang dikurangi tahap demi-tahap selama jangka waktu tertentu. Tujuan kedua adalah untuk menyediakan terapi rumatan (pemeliharaan), yang memberikan metadon secara terus-menerus dengan dosis yang disesuaikan pengguna tidak mengalami gejala putus zat (sakaw).

Penggunaan metadon dalam terapi dinilai paling efektif untuk mengurangi angka penularan HIV melalui jarum suntik terutama dikalangan pengguna napza suntik (penasuan), dibandingkan dnegan terapi subtitusi lainya seperti Subutex dan Naltrakson. Metadon diberikan secara oral dengan dosis disesuaikan dengan kondisi kesehatan pasien dibawah pengawasan dokter atau petugas kesehatan lainnya. Pasien yang menjalani Terapi Rumatan Metadon diharuskan meminm Metadon secara rutin setiap harinya. Pasien harus 
aktif mengakses pelayanan dengan mengunjungi instansi kesehatan yang dilengkapi dengan pelayanan Terapi Rumatan Metadon. Faktor kepatuhan pasien sangat menentukan keberhasilan Program Terapi Rumatan Metadon (Nevi, 2008).

Permasalahan utama dari terapi penyembuhan ketergantungan napza dan penyakit HIV/AIDS yaitu sebagian besar pasien berhenti mengikuti suatu program sebelum mereka merasakan efek terapeutik dari program tersebut. Beberapa faktor yang dihubungkan dengan kepatuhan pasien dalam menjalani perawatan menurut Strain (1999) antara lain motivasi, tingkat keyakinan terhadap program (self efficacy), dukungan keluarga (Wahyu \& Winoto, 2009). Menurut Surveilans Terpadu Biologis Perilaku (2007), penasuan yang terjangkau PTRM cukup besar, namun masih banyak pula yang tetap menyuntik. Dalam menyikapi hal tersebut perlu diperhatikan apasaja yang menghambat kesuksesan program pemerintah seperti hal nya faktor selain yang disebutkan diatas yaitu self control, Seseorang yang sudah mengalami ketergantungan obat sulit untuk dapat menahan atau mengendalikan keinginannya untuk tidak menggunakan barang tersebut. Pergaulan mereka bersama teman, pasangan bahkan anggota keluarga yang menggunakan narkoba akan sulit bagi klien untuk menghindar atau menahan diri agar tidak ikut menggunakannya, berdasarkan hasil observasi dari pasien PTRM mengatakan bahwa mereka kesusahan untuk menghindari menyuntik ketika bersama dengan komunitasnya, dengan terpaksa mereka ikut menggunakan obat-obat tersebut untuk menghargai teman-teman, mencari kepuasa dan rasa nyaman serta menghindari konflik. Salah satu cara untuk dapat menghindari agar tidak kembali menggunakan barang tersebut perlu adanya kontrol diri, dimana kontrol diri dapat diartikan sebagai usaha untuk mengarahkan perilaku, khususnya dalam menahan dorongan/implus dan mampu melawan gangguan atau godaan yang muncul (Baumeister, 2002).

Melalui konesling kelompok, yaitu salah satu teknik yang dapat digunakan untuk membantu PTRM yang memiliki permasalahan yang sama mengenai kontrol diri. Intervensi 
dilakukan dengan berkelompok, hal ini dikarenakan agar para anggota kelompok dapat saling memeberikan motivasi dan membantu subjek untuk mencari solusi secara bersama-sama. Interaksi kelompok memiliki pengaruh yang positif untuk kehidupan individual karena kelompok dapat dijadikan sebagai media terapeutik (Latipun, 2001). Dengan menggunakan konseling kelompok diharapkan kelompok mendapatkan manfaat untuk kedepanya sehingga tidak terulang permasalahan yang sama yaitu dapat menahan diri untuk tidak kembali menggunakan narkoba.

\section{Tinjauan Pustaka}

Kontrol diri merupakan kemampuan individu dalam merespon suatu situasi, kontrol diri sendiri cukup penting peranya bagi masyarakat karena memungkinkan individu untuk menghambat perilaku antisosial. Secara khusus, penelitian terakhir telah menemukan bahwa rendahnya kontrol diri memprediksi peningkatan agresi (DeWall, Baumeister, Stillman, \& Gailliot, 2007; Stucke \& Baumeister, 2006) dan peningkatan berbuat curang (Gino, Schweitzer, Mead, \& Ariely, 2011). Kontrol diri yang rendah juga memprediksi kemauan menurun untuk membantu orang lain (DeWall, Baumeister, Gailliot, \& Maner, 2008).

Baumeister \& Boden (1998) mengemukakan faktorfaktor yang mempengaruhi kontrol diri antara lain: (a.) Orang tua, hubungan anak dengan orang tua memberikan bukti bahwa ternyata orang tua mempengaruhi kontrol diri anakanaknya, orang tua mendidik anak-anaknya dengan keras dan secara otoriter akan menyebabkan anak-anaknya kurang dapat mengendalikan diri serta kurang peka terhadap peristiwa yang dihadapi. Sebaiknya orang tua yang sejak dini sudah mengajari anak untuk mandiri memberikan kesempatan untuk menentukan keputusannya sendiri, maka anak akan lebih mempunyai kontrol diri yang kuat. (b) Faktor budaya, setiap individu yang hidup dalam suatu lingkungan akan terkait pada budaya di lingkungan tersebut. Setiap lingkungan akan mempunyai budaya yang berbeda-beda dengan budaya dari lingkungan lain. Hal demikian mempengaruhi kontrol diri individu sebagai anggota lingkungan tersebut. c. Faktor 
kognitif, yaitu berkenaan dengan kesadaran berupa prosesproses seseorang menggunakan pikiran dan pengetahuanya untuk menggunakan kegiatan yang dilakukan untuk mencapai suatu proses dan cara-cara yang tepat atau strategi yang sudah dipikirkan untuk mengubah stressor. Individu yang menggunakan kemampuan diharapkan dapat memanipulasi tingkah laku sendiri melalui proses intelektual. Jadi kemampuan intelektual individual mempengaruhi seberapa besar individu memiliki kontrol diri.

Skinner mengemukakan bahwa sebuah perilaku menjadi pola kebiasaaan melalui proses penguatan yang disebut perilaku operan. menghasilkan sebuah konsekuensi yang selanjutnya menjadi sebuah kebiasaaan. Kebiasaaan akan terus berkembang selama ada reinforcement positif. Perilaku kecanduan Narkoba pada ke-tujuh subjek terbentuk karena ajakan teman sebaya, serta rasa ingin tahu. Awalnya penggunaa narkoba bersama teman-teman, membuat subjek merasa senang sehingga lama kelamaan membuat subjek kecanduan. Kondisi subjek ketika sakauw sering menunjukkan perilaku agresif, mudah tersinggung serta fisik melemah. Bahkan setelah putus zat mengikuti PTRM, subjek masih sulit untuk melepaskan diri dari kelompok sesama pengguna zat. Menurut subjek, hal ini membuat keluarga subjek merasa tidak nyaman dan tidak bisa menerima keadannya. Kondisi ini membuat subjek lebih nenilih untuk kembali berada di kelompok teman-teman yang memiliki riwayat sesama pecandu napza. Akibatnya, subjek justru terus menggunakan narkoba bersama teman-teman untuk memuasakan kebutuhan kompulsif serta dukungan kebersamaan dengan temna-teman. Kondisi ini semakin membuat subjek sulit mengontrol atau mengendalikan keinginan subjek untuk lepas dari narkoba meskipun mengikuti PTRM.

\section{Metode Penelitian}

Studi ini menggunakan metode one shot case study. Pada metode ini, subjek diberikan suatu intervensi untuk kemudian diamati hasilnya (Latipun, 2015). Subjek dalam study melibatkan 7 pasien laki-laki yang mengikuti program 
terapi rumatan metadon di kota malang dengan rentang usia 22-38 tahun.

\section{Instrumen}

Skala yang digunakan untuk mengukur kontrol diri yaitu menggunakan Self-Control Scale (SCS) yang telah diadaptasi oleh Tangney, J.P., Baumeister, R.F., Boone, A.L. (2004). SCS terdiri dari 10 item pernyataan masing-masing pernyataan disertai dengan empat pilihan jawaban yaitu, sangat sesuai $(S S)=4$, sesuai $(S)=3$, tidak tidak sesuai $(T S)=2$, dan sangat tidak sesuai $($ STS $)=1$

\section{Intervensi dan Hasil Intervensi Intervensi}

Konseling kelompok merupakan salah satu konseling kelompok (group counseling) merupakan salah satu bentuk konseling dengan memanfaatkan kelompok untuk membantu memberi umpan balik (feedback) dan pengalaman belajar. Konseling kelompok prosesnya menggunakan prinsip-prinsip dinamika kelompok (group dynamic) (Gazda, 1989). Konseling kelompok merupakan keompok terapetik yang dilaksanakan untuk membantu klien mengatasi masalah yang berhubungan dengan kehidupan sehari-hari (Latipun, 2005). Konseling kelompok juga merupakan suatu bentuk konseling yang dilakukan oleh seorang konselor untuk memberikan bantuan dalam menyelesaikan permasalahan kepada sekelompok (klien) yang didalamnya terhadap hubungan timbal balik atau interaksi antara konselor dengan sekelompok klien. Intervensi yang dilakukan untuk subjek berupa pemeberian konseling kelompok. Hal tersebut diberikan kepada subjek sebanyak 7 sesi dan disetiap sesinya berdurasi 60 - 90 menit.

Sesi 1-2 akan diberikan inform concent dan menggali informasi dari setiap anggota kelompok mengenai kemampuan dalam anggota kelompok saling kenal dan membuat aturan dalam intirvensi. Anggota kelompok dan terapis mengidentifikasi masalah serta menspesifikasikan masalah serta pemberian pre test untuk mengetahui kondisi awal sebelum diaberikannya intervensi 
Pada sesi 3-4 kelompok menuliskan kelebihan dan kekurangan masing-masing anggota kelompok, meliputi kemampuan mengontrol perilaku, kemampuan mengontrol stimulus, kemampuan mengantisipasi peristiwa, kemampuan menafsirkan peristiwa dan kemampuan mengambil keputusan, sehingga dapat mengetahui kemampuan yang dimiliki setiap individu dan dapat dikembangkan kedepannya sehingga diharapkan mampu untuk mengontrol diri ketika dihadapkan dengan situasi yang menuntut subjek untuk mengambil keputusan secara tepat, sehingga tidak kembali berhubungan dengan narkoba. Selain itu mengambil data dan menganalisis penyebab dengan cara menceritakan kepada anggota kelompok dan meminta feedback dari anggota.

Pada sesi 5 yaitu terapis mengevaluasi kemajuan yang telah dialami oleh anggota kelompok dan mengetahui pemahaman pada setiap anggota kelompok yang diharapkan ada perubahan yang lebih baik serta memberikan pujian kepada anggota kelompok karena telah melakukan yang terbaik untuk kelompok yaitu memberikan pandangan, masukan serta sharing mengenai permasalahan sama yang telah dialami. Untuk sesi terakhir dilakukan pula pengantisipasian dan untuk menangani permasalahan atau mencegah relapse yang akan dihadapi di masa mendatanag serta mengevaluasi secara keseluruhan sesi terapi.

Selanjutnya Sesi 6 akan dilakukan terminasi yaitu berupa penghentian intervensi. Kemudian pada sesi 7 pada sesi ini akan dilakuakn follow up dari keseluruhan kegiatan yang dilakukan.

\section{Hasil dan Pembahsan Hasil}

Intervensi dengan menggunakan konseling kelompok diberikan kepada subjek sebanyak 7 sesi dan disetiap sesinya berdurasi 60 - 90 menit.

Sesi ke-satu membangun rapport pada sesi ini subjek diminta untuk memperkenalkan diri dimulai dengan terapis terlebih dahulu. Selanjutnya terapis membuat kesepakatan dengan semua subjek mengenai keterbukaan dan menyampaikan tujuan serta semua yang akan dibicarakan 
dalam konseling nanti merupakan rahasia dan tidak akan di sampaikan diluar forum konseling. Sesi ini dilakukan agar anggota kelompok merasa nyaman dan saling terbuka mengenai permasalahan yang dialami serta dapat menjalin kepercayaan antar subjek. Disini subjek sudah mulai merasa nyaman dikarenakan subjek sudah saling mengenal satu sama lain dan para subjek rutin bertemu setiap hari dalam mengikuti program terapi rumatan metadon.

Sesi ke-dua, pada sesi ini akan dimulai dengan topic netral yang akan dimulai dari terapis selanjutnya akan dilanjutkan oleh para subjek. Terapis akan memberikan topic netral berupa "kegiatan sehari-hari yang menyenangkan", kemudian subjek diminta untuk menyampaikan masalahnya secara bergantian, kemudian terapis meminta subjek untuk menentukan prioritas dari masalah tersebut dan terapis akan melakukan ekspolorasi dari masalah yang disampaikan secara mendalam serta menspesifikasikan masalah. Seluruh subjek ketika diberikan topic netral dengan tema " kegitan sehari-hari yang menyenangkan" terlihat anggota kelompok mulai membangun suasana yang nyaman. Masing masing subjek menceritkan kegitannya yang menyenangkan seperti pada saat mereka bertemu dengan teman-teman dan keluarga. Seperti yang diungkapkan oleh subjek MF, bahwa ia sangat menyayangi anaknya dan setiap harinya subjek MF meluangkan waktu untuk mengajak bercanda anaknya. Subjek Mf berharap kelak ketika anaknya dewasa tidak mengikuti jejak ayahnya yang berbuhungan dengan obat-obatan terlarang. Pada sesi eksplorasi masalah semua subjek antusias menceritakan masalahnya secara bergantian dan kemudian adanya feedback dari anggota lain menjadikan konseling menjadi sangat kondusif.

Sesi ke-empat, disini terapis mencoba mengklarifikasi kembali masalah yang telah disampaikan di sesi sebelumnya, kemudian subjek diminta untuk menyampaikan kelebihan dan kekurangan masing-masing anggota kelompok, meliputi kemampuan mengontrol perilaku, kemampuan mengontrol stimulus, kemampuan mengantisipasi peristiwa, kemampuan menafsirkan peristiwa dan kemampuan mengambil keputusan, kemampuan-kemampuan tersebut yang dimunculkan pada 
saat berada pada situasi yang menuntut subjek untuk memakai obat-obatan. Kekurangan dan kelebihan dari masing-masing subjek cenderung sama, yaitu sama-sama memiliki harapan untuk bisa melepaskan diri dari obat-obatan namun masih susah untuk mengendalikan diri, subjek mengatakan bahwa pada saat berkumpul dengan kelompok yang berhubungan dengan narkoba, subjek takut untuk menolak, tidak ada ancaman namun khawatir jika memunculkan salah paham. Subjek GF mengatakan bahwa ia sulit untuk mengotrol perilaku untuk tidak memakai pada saat-saat tertentu, seperti pada saat subjek GF merasa jenuh sehingga keinginan untuk meminum kembali muncul dengan tujuan untuk menenangkan fikiran. Subjek $G B$ juga menambahkan bahwa ia tidak mempunyai antisipasi pada saat berada pada situasi yang sama, ia memilih untuk ikut berkumpul dan sesekali ia sudah mencoba untuk menghindar.

Sesi ke-empat, pada sesi ini subjek dan terapis secara bersama-sama mengevaluasi tugas yang diberikan dan mendiskusikanya. Sebelumnya subjek sudah menuliskan beberapa rencana agar bisa mengatasi masalah mengontrol diri, masing-masing anggota kelompok saling mendukung serta sepakat untuk mengurangi pertemuan pada komunitas yang berhubungan dengan obat-obatan, jika terpaksa untuk berkumpul pada komunitas tersebut, subjek menyiapkan antisipasi terlebih dahulu dan menyiapkan jawaban untuk menolak dengan kata-kata yang tidak menyinggung, subjek juga memilih waktu terapi rumatan metadon lebih pagi dari jadwal yang sudah ditentukan, hal tersebut juga disepakatai oleh petugas RM.

Kemudian pada Sesi ke-lima akan dilakukan terminasi yaitu berupa penghentian intervensi. Sesi ke-enam pada sesi ini akan dilakukan follow up dari keseluruhan kegiatan yang dilakukan. Dari hasil follow up yang dilakukan, subjek sudah mulai menujukan perubahan dengan berusaha merubah pola tidurnya sehingga pada malam hari subjek dapat tidur dengan tenang. Intervensi yang telah dilakukan sebanyak 6 sesi dapat diketahui bahwa masing-masing subjek dapat mengidentifikasi permasalahan yang dialaminya dan penyebab dari permasalahan tersebut. subjek juga sudah menemukan solusi 
dimana para subjek sudah memiliki rencana untuk mengontrol diri. Subjek juga sudah mulai mencoba memikirkan dampak negatif yang disebabkan oleh obatobatan terlarang dan dampak positif meninggalkan obatobatan terlarang. Subjek juga sudah menerapkan rencana yang mereka buat sendiri untuk mengatasi masalahnya.

Pemberian konseling kelompok memberikan hasil setiap anggota kelompok dapat saling memberikan penguatan sesama kelompok, subjek juga dapat menemukan berbagai cara dan masukan atau saling sharing mengenai problem yang telah dialami sehingga anggota kelompok dapat memberikan masukan kepada anggota kelompok.

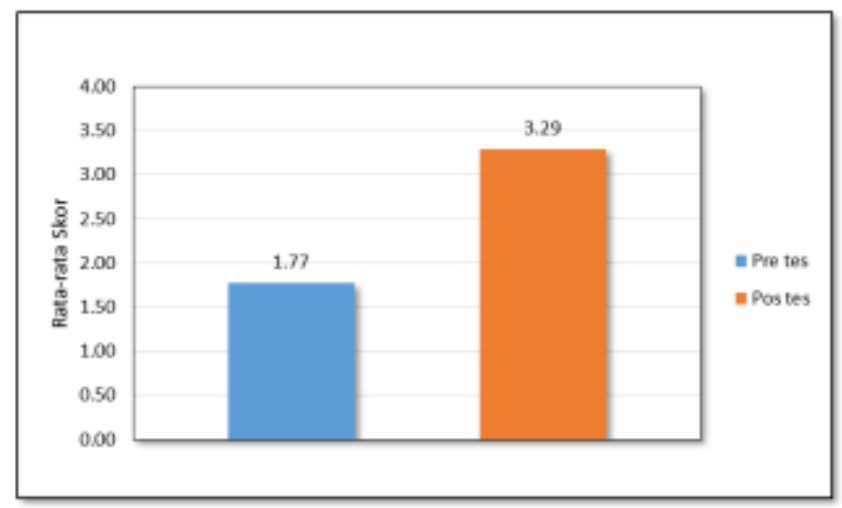

\section{Grafik 1. hasil penilaian selama intervensi}

Grafik tersebut menunjukkan nila test kontrol diri yang dilakukan sebelum (pre tes) dan sesudah perlakuan (pos tes). Nilai tes yang didapat sebelum perlakuan sebesar 1.77 dan nilai tes sesudah perlakuan sebesar 3.29. Hal ini menunjukkan adanya peningkatan kontrol diri pada PTRM, sehingga konseling kelompok yang diberikan dapat meningkatkan self kontrol pada PTRM dalam penggunaan narkoba.

Pada sesi terakhir setiap individu memiliki kontrol diri yang baik, hal tersebut berdasarkan dari tukar pengalaman dimana mereka saling mengingatkan akan tujuan dan target dari dilakukannya treatment. Namun 2 dari ketujuh anggota mengaku masih agak ragu untuk bisa mengontrol diri karena setiap harinya subjek tersebut bekerja bersama salah satu teman yang berhubungan dengan obat-obatan, namun subjek 
tersebut terus berusaha untuk bisa mengontrol diri, ditambah lagi dengan adanya konseling kelompok membuat subjek memahami cara untuk mengontrol diri ketika dihadapkan dengan komunitas yang berhubungan dengan obat-obatan.

Hasil diatas juga menunjukkan sebelum dilakukan intervensi yaitu subjek mudah terpengaruh, tidak bisa mengontrol stimulus, subjek tidak mempunyai antisipasi ketika dihadapkan dengan stimulus yang menuntutnya untuk ikut minum memakai obat-obatan, sehingga susah untuk menolak ajakan teman-temanya dan juga subjek tidak bisa mengambil keputusan dengan tepat. Setelah diberikan intervensi subjek menunjukkan perubahan diantaranya adalah Subjek mampu untuk mengontrol perilaku ketika diajak untuk berkumpul bersama komunitas tersebut, subjek mampu mengontrol stimulus, subjek mampu untuk antisipasi peristiwa dan pada saat subjek diminta untuk bergabung dengan teman-teman, subjek sudah menyiapkan alasan utuk menolak dan mampu mengambil keputusan.

\section{Pembahasan}

Dengan adanya dukungan dan adanya penguatan dalam hal ini adalah kelompok dapat mendukung seseorang memiliki rasa lebih percaya diri, lebih dapat menahan keinginan untuk kembali dalam menggunakan oabat-obatan terlarang dan dapat meningkatkan fungsi psikis lainnya. Menurut Heller yang dikutip Chan \& Thompson (2006) menyatakan bahwa hasil penelitian adalah dukungan kelompok berhubungan dengan peningkatana fungsi secara psikologis, sedangkan dukungan yang bermanfaat adalah suatu proses partisipasi dimana terjadi aktifitas berbagai pengalaman (sharing eperiences), situasi, dan masalah yang difokuskan pada prinsip memberi dan menerima, mengaplikasikan ketrampilan bantu diri (self help), saling membantu dan pengembangan pengetahuan setiap individu.

Secara keseluruhan anggota kelompok dapat melakukan kontrol diri yang baik terlihat dari kegiatan yang dilakukan pada saat setelah dilakukan pembahasan mengenai permasalahan dan menetapkan tujuan dari kegiatan yang akan dilakukan kemudian sesi selanjutnya dengan membuat 
komitmen untuk berubah adalah dengan memanfaatkan lingkunga terutama teman-teman dekat untuk mengingatkan komitmen dan tujuan dari treatment. Pada sesi ketiga setiap anggota kelompok menganalisis penyebab yang dialami dengan menceritakan kepada teman mengenai program ynag dijalani dan meminta feedback dari setiap anggota kelompok.

Sesi keempat dibuat situasi dimana setiap anggota kelompok menginstruksikan pada diri sendiri untuk dapat mengontrol diri apabila terlintas memikirkan narkoba, kemampuan mengontrol stimulus, kemampuan mengantisipasi peristiwa, kemampuan menafsirkan peristiwa dan kemampuan mengambil keputusan, dengan membuat target perilaku yang ingin dicapai hingga maksimal dan menghindari reinfircement yang dapat memperkuat perilaku. Kemudian pada sesi 5 dilakuakn evaluasi dan memberikan beberapa pekepujian serta support dari masing-masing anggota mengenai kemajuan yang telah dilakukan.

Peran terapis membantu anggota kelompok dalam memberikan beberapa pandangan untuk mempertahankan control diri serta memberikan pandangan beberapa aktifitas tambahan yang menjadikan individu sibuk, sehingga kecil kemungkinan untuk kembali berkumpul dengan komunitas yang berhubungan dengan obat-obatan terlarang. Pada sesi terakhir dilakaukan pengantisipasian untuk mencegah terjadinya relaps dan membuat target perilaku yang lebih konkrit dan spesifik. Kelebihan dalam konseling kelompok yang dilakukan oleh para anggota kelompok memberikan pandangan baru mengenai tinjauan kembali ketika dihadapkan dengan stimulus yang menuntut untuk ikut serta memakai obat-obatan terlarang, individu dapat menahan diri agar tidak kembali menggunakan obat-obatan terlarang.

\section{Kesimpulan}

Pemberian konseling kelompok dapat membantu untuk meningkatkan kontrol diri pada individu pengguna narkoba yang sedang menjalani terapi rumatan metadon, hal tersebut efektif karena adanya dorongan dan keinginan dari individu, serta dukungan dari orang sekitar untuk berusaha merubah 
kehidupan di masa mendatang yang lebih baik dan membantu seseorang meningkatkan kontrol diri.

Diharapkan untuk anggota kelompok memiliki aktifitas ataupun kesibukan yang lebih positif, sehingga waktu untuk berkumpul dengan komunitas yang berhubungan dengan narkoba menjadi berkurang, dan berdampak pada terapi rumatan metadon yang sedang dijalani bisa berjalan dengan maksimal, dan menjaga kekambuhan pasca mengikuti terapi rumatan metadon. 


\section{Daftar Pustaka}

Baumeister R, dan. Boden, J. 1998. Aggression And The Self: $\mathrm{H}$ Igh Self-Esteem, Ow Self-Control, And Ego Threat Human Aggression: Theories, Research, and Implications for Social Policy Case Western Reserve Universit

Caplehorn, J., R \& Bell., J,. (1991). Metadhone dosage and retention of patiets in maintenance. International journal of the addiction, 154 (3), 195-5

DeWall, C. N., Baumeister, R. F., Stillman, T. F., \& Gailliot, M. T. (2007). Violence restrained: Effects of selfregulatory capacity and its depletion on aggressive behavior. Journal of Experimental Social Psychology, 43, 62-76.

DeWall, C. N., Baumeister, R. F., Gailliot, M. T., \& Maner, J. K. (2008). Depletion makes the heart grow less helpful: Helping as a function of self-regulatory strength and genetic relatedness. Personality and Social Psychology Bulletin, 34, 1653-1662.

Gifari., S., A,. (2009). “Dukungan total untuk memotong penyebarana HIV/AIDS melalui jarum suntik. http://kesehatan.kompasiana.com. diakses tanggal 03 oktober 2010.

Gino, F., Schweitzer, M. E., Mead, N. L., \& Ariely, D. (2011). Unable to resist temptation: How self-control depletion promotes unethical behavior. Organizational Behavior and Human Decision Processes, 115, 191- 203

Latipun. 2001. Psikologi Konseling (edisi ketiga). Malang: UMM University Press

Lasisi, J., C., Emeka, O., J., Onongha., I., G., \& Ushie., A., M, (2012). Analysis of the effect of group counseling on the copping behavior of people living with hiv/aids in yakurr local government area, cross river state. Academic Research International. 3, (2), 2223-9553. 
Michael, J., Telch., Christy, F., \& Telch. (1986). Group coping skills instruction and supportive group therapy for cancer patients:A comparison. Journal of Consulting and Clinical Psychology, 54 (6), 802-808.

Nevi, N.. (2010). Terapi metadon cegah penularan HIVAIDS pada penasua". http://kesehatan.kompasiana.com. diakses tanggal 03 oktober 2010.

Rathus, S.A., \& Nevid., J., J. (1991). Abnormal Psychology. New Jersey : Prentice Hall, Englewood Cliffs.

Sarwono. (2010). Psikologi kognitif edisi kedelepan. Jakarta: Erlangga

Synder, S.,R. \& Lopez., S., J., (2005). Handbook of positive psychology. Oxford university press.

Tangney, J.P., Baumeister, R.F., Boone, A.L. (2004). High selfcontrol predicts good adjustment, less pathology, better grades, and interpersonal success. Journal of Personality, 271-324.

Woolfolk, Robert L., McNulty Terrence F. (1983). Group counseling: A componen analysis. Journal of Consulitng and clinical Psychology. 51(4), 495-503

Yuniardi, S., M \& Djudiyah, (2011). Model pengembangan konsep diri melalui ssupport group therapy: Upaya meminimalkan trauma psikis remaja dari keluarga single parent. Jurnal Psikologi Proyeksi, 6, (1), 16-26 